\section{Populærvitenskapelig om hjertet}

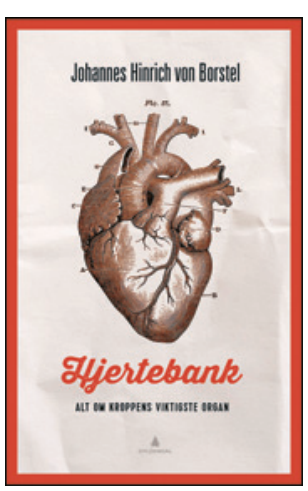

Johannes Hinrich von Borstel Hjertebank

Alt om kroppens viktigste organ. 303 s, ill.

Oslo: Gyldendal, 2016. Pris NOK 349

ISBN 978-82-05-49301-8

I Hjertebank tar forfatteren for seg alt om hjertets funksjon og alle tenkelige sykdommer fra medfødt hjertefeil til atherosklerotiske sykdommer og fatale hendelser som hjertestans. Risikofaktorer for hjertesykdom omtales naturlig nok i denne sammenheng, i tillegg til en rekke tema med varierende relevans for hovedtemaet, som infeksjonsforsvar, immunologi, endokrinologi, blodets innhold, blodtrykksregulering, vaksinasjon, unnvikelsesatferd, trening, diabetes og doping.

Forfatteren av Hjertebank er en tysk medisinstudent med interesse for kardiologi og med bakgrunn fra ambulansetjenesten. Han skal være en anerkjent «science slammer», hvilket betyr at han er vant til å presentere vitenskap på en forståelig, underholdende og konsis måte for folk flest.

Forklaringene er svært detaljerte og i lett forståelig språkdrakt, men i tillegg oppgis det korrekte fagordet for den anatomiske strukturen eller prosessen. Det betyr at i løpet av bokens 300 sider vil man uten helsefagutdanning møte utrolig mange fremmedord. Ved et par utsagn oppgir forfatteren at det ikke er enighet i fagmiljøet. Det tror jeg gjelder flere utsagn, særlig i avsnittet om kosthold. Det foreligger noen referanser bakerst, men listen er nokså ufullstendig.

Underveis lurer jeg på hvem Hjertebank er mest egnet for? For kardiologer vil det være lite nytt å lære, og man vil kanskje irritere seg over utsagn som ikke er helt korrekte og litt omstendelige forklaringer. Nevrologer vil antagelig av prinsipp ikke lese noe som har undertittelen «Kroppens viktigste organ» uten å handle om hjernen. Kapitlene har svært spennende overskrifter, men innholdet fremstår ikke like spennende. Assosiasjonene og de populærvitenskapelige fremstillingene er ikke morsomme nok. Jeg tar meg i å savne illustrasjonene til Trond Viggo fra Kroppen, for det er få illustrasjoner. Noen setninger er litt tunge, muligens fordi de norske uttrykkene man bruker i det daglige ikke er kjent av oversetter? Jeg testet ut et kapittel på en ingeniør, det var ikke så vellykket.

Nå skal det sies at forfatteren virker svært kunnskapsrik innen fagfeltet kardiologi og han diskuterer svært sentrale temaer. Mye av det han omtaler har nok gått i glemmeboka for mange av oss, og den kan sånn sett inspirere til repetisjon og fordypning i utvalgte temaer. Kanskje vil likevel de som er i starten av en helsefagutdanning kunne ha størst glede av å lese denne.

\section{Ellen Bøhmer}

Overlege, Avdeling for indremedisin

Sykehuset Innlandet Lillehammer

og

Geir Høgalmen

Overlege, Avdeling for indremedisin

Sykehuset Innlandet Lillehammer

\section{Metalegevakt}

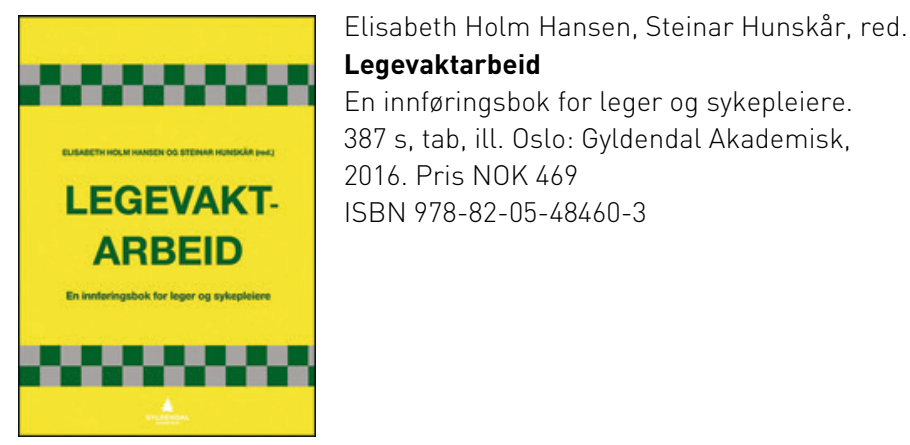

Fra Gyldendal Akademisk har det kommet en bok om legevaktmedisin som vil være lett synlig i bokhyllen. Omslaget er passende nok neongult og beredskapsaktig. Det er første gang vi har en norsk bok dedikert til legevakten, og den fyller fint en hittil tom nisje.

Fremfor å være en medisinsk lærebok tar den for seg legevaktens rolle, rammer, pasientgrupper, ledelse, kvalitetsarbeid, kompetanseutvikling og tanker om fremtiden. Noen kliniske kasuistikker er det også, men mer for å belyse pasientforløpene. Den er logisk inndelt, lettlest, delvis illustrert, og med flere tabeller, slik vi er vant til fra medisinske bøker fra samme forlag.

Det mest fornøyelige å lese var refleksjonene rundt hva som er spesielt med legevakt kontra allmennpraksis og sykehus hva gjelder diagnostikk og behandling. På legevakt er man opptatt av å løse de oppgavene som ikke med forsvarlighet kan vente, og det synes jeg forfatterne drøfter godt. Omtale av begreper innen beslutningskompetanse (positiv- og negativ prediktiv verdi, pre- og posttest med mer) og verdier av kliniske og supplerende undersøkelser er spesielt solid. Utgivelsens mål er angitt blant annet å skulle forene de ulike faggruppene som sykepleiere, legevaktleger, turnusleger og paramedics i en felles tanke om å gi best mulig pasientopplevelse og kvalitet. Dette tror jeg den vil få til.

Jeg savner mer omtale av det nye nødnettet og praktisk bruk av dette som legevaktlege. Videre er det mange praktiske aspekter og refleksjoner rundt legevaktdrift i fjernere distrikter som godt kunne vært tatt opp. Den er nok også mindre relevant for medisinstudenter.

I det store og hele var dette en kjekk bok å lese da jeg jobbet som legevaktlege. Den er nok desto mer verdifull for sykepleieren jeg hadde foran meg i frontlinjen. Da jeg tittet innom vaktrommet på min siste vakt nylig lå Legevaktarbeid så i hyllen hennes også.

\section{Stian Wendelborg}

Lege i spesialisering i kirurgi, Nordlandssykehuset Vesterålen 